\title{
Delusional parasitosis (Ekbom syndrome) - a psychodermatologic disorder
}

\section{Obłęd pasożytniczy (choroba Ekboma) - zaburzenie psychodermatologiczne}

\author{
Jagoda Stroynowska-Kosik, Sandra Zyzak, Ewelina Biało-Wójcicka \\ Dermatology Ward for Adults, Międzylesie The Tertiary Hospital, Warsaw, Poland \\ Oddział Dermatologii Dorosłych, Międzyleski Szpital Specjalistyczny w Warszawie, Polska \\ Dermatol Rev/Przegl Dermatol 2021, 108, 160-168 \\ DOI: https://doi.org//0.5 I |4/dr.2021. 107288
}

\author{
CORRESPONDING AUTHOR/ \\ ADRES DO KORESPONDENCJI: \\ dr n. med. Ewelina Biało-Wójcicka \\ Oddział Dermatologii Dorosłych \\ Międzyleski Szpital \\ Specjalistyczny \\ ul. Bursztynowa 2 \\ 04-749 Warszawa \\ tel.: +48504694057 \\ e-mail: ewelbialo@poczta.onet.pl
}

\begin{abstract}
Introduction. Delusional parasitosis is a psychotic disorder characterized by an isolated delusional judgment about the presence of parasites moving under or in the skin.

Objective. Presentation of a case of delusional parasitosis in a patient treated with psychoactive drugs.

Case report. A 73-year-old woman was admitted to the hospital because of extensive erosive skin lesions. Skin lesions with associated itching have been present for about 7 years. The patient associated them with a parasitic infection with nematodes. The patient reported that she was intentionally infected by a person that she met in a public place. Testing for parasitic infestations gave repeatedly negative results. The patient was treated with antiparasitic preparations with no satisfactory improvement. Histology image showed features corresponding to prurigo nodularis. After consultation with a psychiatrist, during the hospital stay, the antipsychotic treatment with olanzapine was started at the dose of $10 \mathrm{mg} /$ day with a good response to treatment.

Conclusions. Knowledge of psychodermatological conditions in everyday clinical practice may contribute to the improvement of diagnostics and faster implementation of effective treatment of psychodermatoses.
\end{abstract}

\section{STRESZCZENIE}

Wprowadzenie. Obłęd pasożytniczy jest zaburzeniem psychotycznym, charakteryzującym się pojedynczym sądem urojeniowym co do obecności pasożytów poruszających się pod skórą i/lub w skórze.

Cel pracy. Przedstawienie przypadku obłędu pasożytniczego u pacjentki leczonej lekami psychiatrycznymi.

Opis przypadku. Kobieta 73-letnia została przyjęta na oddział z powodu rozległych zmian nadżerkowych na skórze. Zmiany skórne ze świądem występowały od około 7 lat. Pacjentka wiązała je z infekcją pasożytniczą nicieniami. Twierdziła, że została celowo zarażona przez osobę przypadkowo spotkaną w miejscu publicznym. W wielokrotnie wykonanych badaniach w kierunku potwierdzenia infekcji pasożytniczej uzyskiwała wyniki ujemne. Leczona preparatami przeciwpasożytniczymi - bez zadowalającej poprawy. W obrazie histologicznym stwierdzono obraz mogący odpowiadać prurigo nodularis. Po konsultacji z lekarzem psychiatrą w trakcie pobytu w szpitalu włączono lecze- 
nie przeciwpsychotyczne olanzapiną w dawce $10 \mathrm{mg} /$ dobę i uzyskano dobrą odpowiedź.

Wnioski. Znajomość problematyki z zakresu psychodermatologii w codziennej praktyce klinicznej może się przyczynić do poprawy diagnostyki i szybszego wdrożenia skutecznego leczenia psychodermatoz.

Key words: psychodermatology, psychotic disorder, parasitosis, delusional parasitosis.

Słowa kluczowe: psychodermatologia, zaburzenia psychiczne, parazytoza, obłęd pasożytniczy.

\section{INTRODUCTION}

Mental factors play an important role in many dermatological diseases. The relationship between the mental state and the skin is bi-directional. Presence of skin lesions has a negative impact on the patient's mental state, while the patient's emotional state, such as anxiety, depressed mood or stress, may exacerbate symptoms of dermatological diseases.

The problem of a relationship between the skin and the mental health is dealt with by a relatively young field of medicine - psychodermatology. It combines issues from the border of dermatology, psychiatry and psychology $[1,2]$.

It is estimated that mental disorders, both primary and secondary, occur in about $15 \%$ of patients visiting dermatology clinics [3]. Diseases included in the group of psychodermatological conditions include: psychophysiological disorders, mental disorders secondary to dermatological diseases and primary mental disorders with dermatological manifestations [1, 2, 4]. In their treatment, apart from dermatological therapy, psychological support, psychotherapy, and in some cases also psychiatric treatment are also important. Knowledge of psychodermatological problems in everyday clinical practice may contribute to improved diagnostics and faster implementation of effective treatment of psychodermatoses.

\section{OBJECTIVE}

The paper describes the case of a 73-year-old patient diagnosed with delusional parasitosis, in the treatment of whom the cooperation of doctors representing different fields of medicine - a dermatologist and a psychiatrist - was of great importance.

\section{CASE REPORT}

The 73-year-old female patient was admitted to the Dermatology Ward due to numerous erosions,

\section{WPROWADZENIE}

Czynniki psychiczne odgrywają istotną rolę w przebiegu wielu chorób dermatologicznych. Związek między stanem psychicznym i skórą jest dwukierunkowy. Obecność zmian skórnych wpływa negatywnie na stan psychiczny pacjenta, natomiast stan emocjonalny chorego, np. lęk, obniżony nastrój lub stres, może nasilać objawy chorób dermatologicznych.

Problematyką zależności między skórą a psychiką zajmuje się stosunkowo młoda dziedzina medycyny, jaką jest psychodermatologia. Łączy ona w sobie zagadnienia z pogranicza dermatologii, psychiatrii i psychologii $[1,2]$.

Szacuje się, że pierwotne i wtórne zaburzenia psychiczne występują u około $15 \%$ pacjentów zgłaszających się do poradni dermatologicznych [3]. Wśród chorób psychodermatologicznych wyróżnia się: zaburzenia psychofizjologiczne, zaburzenia psychiczne wtórne do chorób dermatologicznych oraz pierwotne zaburzenia psychiczne mające manifestację skórną $[1,2,4]$. W ich leczeniu, oprócz terapii dermatologicznej, istotne znaczenie ma wsparcie psychologiczne, psychoterapia, a w niektórych przypadkach również leczenie psychiatryczne. Znajomość problematyki z zakresu psychodermatologii w codziennej praktyce klinicznej może się przyczynić do poprawy diagnostyki i szybszego wdrażania skutecznego leczenia psychodermatoz.

\section{CEL PRACY}

W artykule opisano przypadek 73-letniej pacjentki z diagnozą obłędu pasożytniczego, w której leczeniu istotne znaczenie miała współpraca lekarzy odrębnych dziedzin medycyny - dermatologa i psychiatry.

\section{OPIS PRZYPADKU}

Pacjentka 73-letnia została przyjęta na Oddział Dermatologii z powodu licznych nadżerek, przeczo- 
excrescences, scratches within the skin of the trunk and limbs, and alopecia foci on the scalp. Skin lesions accompanied by pruritus have been present for about 7 years. The patient associated them with a parasitic infection with nematodes. According to her relation, she was purposefully infected by a person accidentally met in a public place. The patient performed numerous microbiological tests on her own, which did not confirm presence of any parasitic infection. She was treated many times with antiparasitic preparations - pyrantel, mebendazole and albendazole without a satisfactory improvement. In addition, in the medical history the patient reported hospitalization at the Department of Neuroses at the Institute of Psychiatry and Neurology in Warsaw in 1991-1992. Currently, she has not been under psychiatric care for many years.

On admission, she reported skin itching, sensation of nematodes crawling in her skin. She demanded attention, talked about her ailments willingly and in detail. As evidence of a parasitic infection, she showed a "collection of nematodes" - a foil bag containing "worms" collected by the patient (the socalled "sample symptom" /"matchbox" symptom), in which the presence of damaged epidermis, hair, fibers from clothing were found (fig. 1). Dermatological examination of the trunk and limbs revealed numerous disseminated erythematous-erosive lesions, scratches and excrescences, and scars from previous skin lesions (fig. 2). There was a noticeable asymmetry of skin lesions, the so-called "hand effect", intensification of changes located on the side opposite to the dominant hand. Extensive foci of alopecia on the scalp. A trichoscopic examination demonstrated a presentation corresponding to trichotillomania. During hospitalization, a specimen of the skin lesion was taken for histopathological examination.

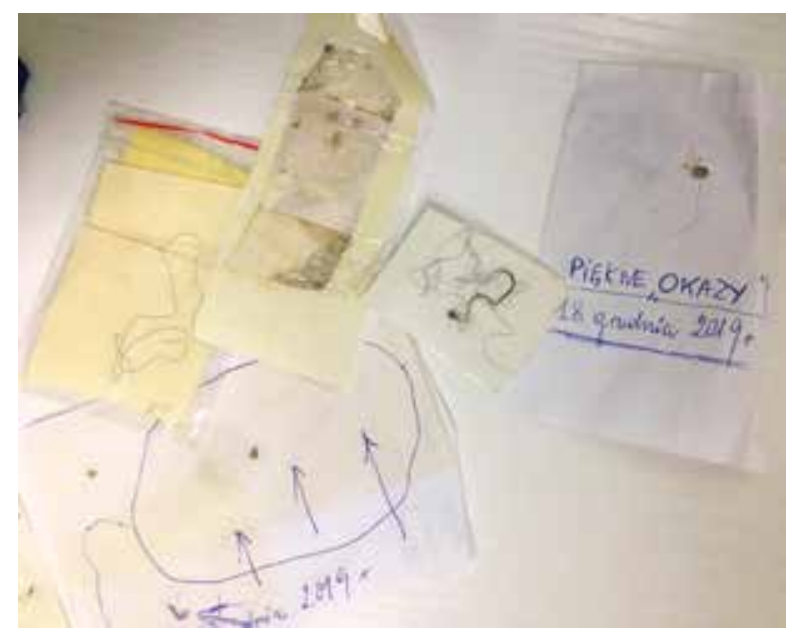

Figure I. Materials collected by the patient. Alleged "parasites" Rycina I. Materiały zebrane przez pacjentkę, uważane przez nią za pasożyty sów, wydrapań w obrębie skóry tułowia i kończyn oraz ognisk wyłysienia w obrębie owłosionej skóry głowy. Zmiany skórne $\mathrm{z}$ towarzyszącym świądem występowały od około 7 lat. Kobieta wiązała je z infekcją pasożytniczą nicieniami. Twierdziła, że została celowo zarażona przez osobę przypadkowo spotkaną w miejscu publicznym. Chora na własną rękę wykonała liczne badania mikrobiologiczne, które nie potwierdziły infekcji pasożytniczej. Wielokrotnie była leczona preparatami przeciwpasożytniczymi - pyrantelem, mebendazolem i albendazolem - bez zadowalającej poprawy. Poza tym w wywiadzie podawała hospitalizację w Klinice Nerwic w Instytucie Psychiatrii i Neurologii w Warszawie w latach 1991-1992. Obecnie od wielu lat nie była pod opieką psychiatryczną.

Przy przyjęciu zgłaszała świąd skóry, uczucie pełzania nicieni w skórze. Domagała się uwagi personelu, chętnie i szczegółowo opowiadała o dolegliwościach. Jako dowód infekcji pasożytniczej pokazywała ,kolekcję nicieni" - foliowy woreczek zawierający zebrane przez pacjentkę „robaki” (tzw. objaw próbki/objaw pudełka zapałek), w którym znajdowały się fragmenty uszkodzonego naskórka, włosy, włókna z odzieży (ryc. 1). W badaniu dermatologicznym w obrębie tułowia i kończyn stwierdzono liczne rozsiane zmiany rumieniowo-nadżerkowe, wydrapania i przeczosy oraz blizny po poprzednich zmianach skórnych (ryc. 2). Zauważalna była asymetria zmian, tzw. efekt ręki, czyli nasilenie zmian po stronie przeciwnej do ręki dominującej. W obrębie skóry owłosionej głowy występowały rozległe ogniska wyłysienia. Obraz w badaniu trichoskopowym odpowiadał trichotillomanii. W czasie hospitalizacji pobrano wycinek ze zmiany skórnej do

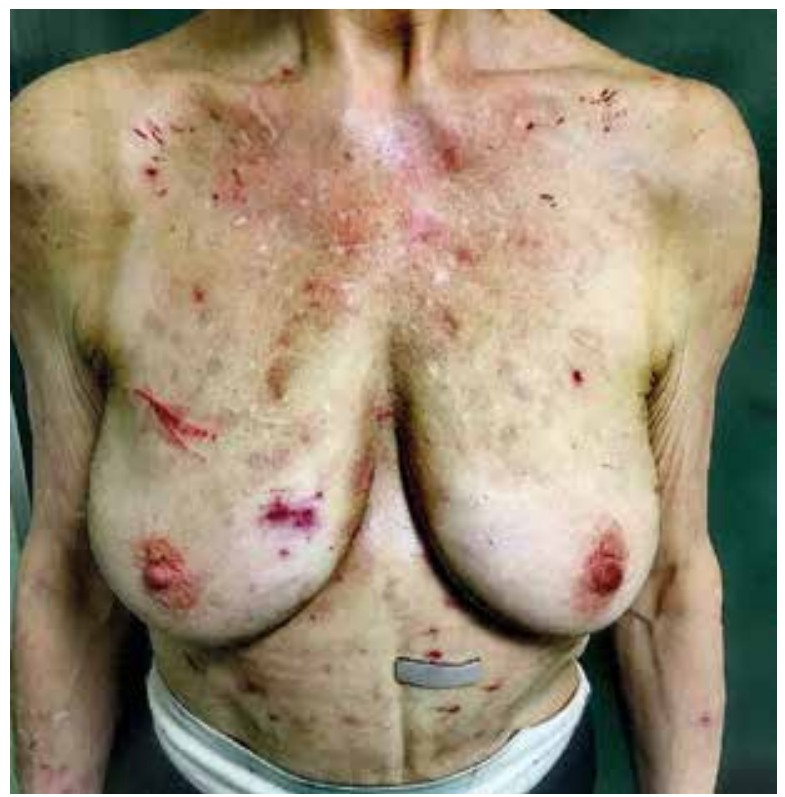

Figure 2. Erosions and excrescences on the trunk

Rycina 2. Zmiany nadżerkowe, przeczosy na tułowiu 
The microscopic image showed the presentation that could correspond to prurigo nodularis. After consultation with a psychiatrist, during the hospital stay, olanzapine was started at the dose of $10 \mathrm{mg} /$ day and hydroxyzine at the dose of $3 \times 25 \mathrm{mg}$. Topical wound disinfection with hypochlorite preparations and hydrocolloid dressings were used to treat skin lesions. A gradual improvement in the mental and local status was observed. The patient was referred to the Mental Health Clinic in order to continue the treatment.

\section{DISCUSSION}

Delusional parasitosis, also referred to as parasitic hallucinosis, parasitic delusions or Ekbom's syndrome, is a relatively rare psychotic disorder classified as somatic delusional disorder according to the ICD-10 classification [5].

It is characterized by a patient's strong, false belief about presence of parasites on the surface or deep inside the skin (less often bacteria, fungi, viruses), despite the lack of any medical evidence of the existence of parasitic infection $[1,6]$. This belief is usually supported by various sensory sensations, such as itching or burning of the skin. These experiences may have a psychological basis, be a manifestation of a somatic disease, or may be secondary to skin self-injury caused by the patient [7]. Due to its frequent skin manifestations, this disease is closely related to dermatology. It is one of the basic diseases that psychodermatology deals with. According to the classification of psychodermatoses, delusional parasitosis is classified as a primary mental disorder with a dermatological manifestation [1, 2, 4]. Delusional parasitosis can be divided into primary, secondary and organic. In the original form, the patient, apart from the strong belief that he/she is infected with parasites, does not present any other mental or organic disorders. The secondary form is characterized by the presence of additional mental disorders, e.g., dementia, obsessive compulsive disorder, bipolar disorder or schizophrenia. In turn, the organic form of parasitic insanity is associated with other somatic diseases (e.g. hypothyroidism, anemia, vitamin $B_{12}$ deficiency, hepatitis, diabetes, syphilis, AIDS), or with medications used by the patient (e.g. with glucocorticoids, interferon, clarithromycin and ciprofloxacin) or psychoactive substances (e.g., cocaine, amphetamines, cannabinoids) $[1,6]$.

Apart from that, there is also an induced delusional disorder or shared delusion (from French folie a deux). It is estimated that this disorder occurs in about $5-15 \%$ of cases. It consists in the presence of identical delusional disorders in people from the patient's immediate surroundings. Interestingly, symp- badania histopatologicznego. W obrazie mikroskopowym stwierdzono obraz mogący odpowiadać prurigo nodularis. Po konsultacji z lekarzem psychiatrą w trakcie pobytu w szpitalu włączono olanzapinę $\mathrm{w}$ dawce $10 \mathrm{mg} /$ dobę oraz hydroksyzynę w dawce $3 \times 25 \mathrm{mg}$. W leczeniu zmian skórnych stosowano miejscowo odkażanie ran preparatami z grupy podchlorynów oraz opatrunki hydrokoloidowe. Obserwowano stopniową poprawę stanu psychicznego i miejscowego. Pacjentkę skierowano do poradni zdrowia psychicznego w celu kontynuacji leczenia.

\section{OMÓWIENIE}

Obłęd pasożytniczy, znany również jako parazytoza urojeniowa, halucynoza pasożytnicza, urojenia pasożytnicze lub zespół Ekboma, jest stosunkowo rzadkim zaburzeniem psychotycznym, zaliczanym zgodnie z klasyfikacją ICD-10 do grupy organicznych zaburzeń urojeniowych [5].

Charakteryzuje się silnym, fałszywym przekonaniem chorego o obecności na powierzchni lub w głębi skóry pasożytów (rzadziej bakterii, grzybów, wirusów) pomimo braku jakichkolwiek medycznych dowodów na istnienie infekcji [1, 6]. Przekonanie to zazwyczaj poparte jest różnymi doznaniami czuciowymi, np. świądem, uczuciem pieczenia lub palenia skóry. Doznania te mogą mieć podłoże psychologiczne, być manifestacją chorób somatycznych lub występować wtórnie do samouszkodzeń skóry dokonywanych przez chorego [7]. Choroba ta ze względu na częstą manifestację skórną jest ściśle powiązana $\mathrm{z}$ dermatologią. Stanowi jedno z podstawowych schorzeń, którymi zajmuje się psychodermatologia. Według klasyfikacji psychodermatoz obłęd pasożytniczy zaliczany jest do pierwotnych zaburzeń psychicznych mających manifestację skórną $[1,2,4]$. Parazytozę urojeniową można podzielić na postać pierwotną, wtórną i organiczną. W postaci pierwotnej pacjent, oprócz silnego przekonania, że jest zarażony pasożytami, nie ma innych zaburzeń psychicznych lub organicznych. Postać wtórna charakteryzuje się obecnością u pacjenta dodatkowych zaburzeń psychicznych, takich jak demencja, zaburzenia kompulsywno-obsesyjne, choroba afektywna dwubiegunowa lub schizofrenia. Natomiast postać organiczna obłędu pasożytniczego ma związek z innymi schorzeniami somatycznymi (np. niedoczynnością tarczycy, niedokrwistością, niedoborem witaminy $\mathrm{B}_{12}$, zapaleniem wątroby, cukrzycą, kiłą, AIDS) lub z przyjmowanymi przez chorego lekami (np. glikokortykosteroidami, interferonem, klarytromycyną, ciprofloksacyną) i substancjami psychoaktywnymi (np. kokainą, amfetaminą, kannabinolami) $[1,6]$.

Poza tym wyróżnia się obłęd pasożytniczy udzielony, znany w piśmiennictwie jako indukowane 
toms usually disappear after the patients are separated from each other $[1,6]$.

Exact epidemiological data on the incidence of delusional parasitosis are not known. Commonly, this disease is considered rare. The annual incidence rate is estimated at approximately 16.6 cases per million [8]. A survey conducted among Polish dermatologists showed that as many as $85 \%$ of them encountered at least one case of parasitic insanity in their daily practice [9].

It is known that this disease occurs more commonly in women - the overall ratio of affected women to men is estimated at $2: 1$. Among young patients the ratio is $1: 1$, and for people over 50 years of age it is $3: 1[1,10]$. The estimated mean age of onset is 57 years $[8,11]$.

It is assumed that delusional parasitosis more often affects mainly people living in social isolation, of low socioeconomic status and basic education, which is especially visible in the group of younger patients [12]. Moreover, the disease is more frequently associated with the use of psychoactive substances among younger patients [1].

The pathogenesis of delusional parasitosis remains unclear. It appears that, as in the case of other delusional disorders, disorders of neurotransmission in the central nervous system, mainly involving the dopaminergic system, are at the root of this disorder. It is now believed that decreased transporter activity plays a key role in the etiopathogenesis of this disease dopamine in the striatum, which results in an increase in extracellular dopamine concentration [13]. This hypothesis is confirmed by observations of occurrence of delusional parasitosis in patients with neurodegenerative diseases, such as Huntington's chorea, Alzheimer's disease or vascular dementia [14]. Many other disorders have been shown to cause a secondary or organic form of delusional parasitosis, including, but not limited to: schizophrenia, depression, alcoholism, vitamin $\mathrm{B}_{12}$ and iron deficiency are associated with impaired dopaminergic conduction [6]. Some believe that a traumatic event in the patient's life may be a trigger for the development of this disease. Unable to cope with a difficult situation, the patient activates defense mechanisms, taking the form of transference. As a result, the emotions related to the unpleasant event are replaced by the symptoms of delusional parasitosis [12].

The basic symptom of delusional parasitosis is the patient's false and solid belief that parasites (less often bacteria, fungi, viruses) are present in or on the skin. Sometimes patients report presence of parasites in their environment, e.g., on clothes, bedding, furniture $[1,8]$. This belief is maintained despite the lack of any medical evidence of existence of parasitic infection $[1,6]$. Lack of criticism towards productive zaburzenie urojeniowe lub obłęd udzielony ( $\mathrm{z}$ fr. folie $a^{\prime}$ deux). Szacuje się, że zaburzenie to występuje w około 5-15\% przypadków. Polega ono na obecności identycznych zaburzeń urojeniowych u osób z najbliższego otoczenia pacjenta. Objawy zazwyczaj ustępują po odizolowaniu od siebie chorych $[1,6]$.

Dokładne dane epidemiologiczne na temat częstości występowania obłędu pasożytniczego nie są znane. Powszechnie chorobę tę uważa się za rzadko diagnozowaną. Roczny wskaźnik zachorowalności szacuje się na około 16,6 przypadku na milion [8]. Badanie ankietowe przeprowadzone wśród polskich dermatologów wykazało, że aż 85\% z nich spotkało się z przynajmniej jednym przypadkiem obłędu pasożytniczego w swojej codziennej praktyce [9].

Wiadomo, że choroba ta częściej występuje u kobiet - ogólny stosunek chorych kobiet do mężczyzn szacuje się na $2: 1$. Wśród pacjentów młodych stosunek ten wynosi $1: 1$, natomiast wśród osób powyżej 50. roku życia 3 : $1[1,10]$. Szacunkowo średni wiek zachorowania to 57 lat $[8,11]$.

Przyjmuje się, że obłęd pasożytniczy dotyczy głównie osób żyjących w izolacji społecznej, o niskim statusie socjoekonomicznym i niskim wykształceniu, co szczególnie widoczne jest u młodszych pacjentów [12]. Poza tym wśród młodszych chorych częściej obserwuje się związek choroby ze stosowaniem substancji psychoaktywnych [1].

Patogeneza parazytozy urojeniowej jest nieznana. Wydaje się, że podobnie jak w przypadku innych zaburzeń urojeniowych u podstaw tego schorzenia leżą zaburzenia neuroprzekaźnictwa w ośrodkowym układzie nerwowym, głównie dotyczące układu dopaminergicznego. Obecnie uważa się, że kluczową rolę w etiopatogenezie tej choroby odgrywa zmniejszona aktywność transportera dopaminy w prążkowiu, co skutkuje wzrostem pozakomórkowego stężenia dopaminy [13]. Hipotezę tę potwierdzają obserwacje dotyczące występowania obłędu pasożytniczego u pacjentów z chorobami neurodegeneracyjnymi, np. pląsawicą Huntingtona, chorobą Alzheimera i otępieniem naczyniopochodnym [14]. Wykazano, że wiele innych zaburzeń będących przyczyną wtórnej lub organicznej postaci obłędu pasożytniczego, w tym schizofrenia, depresja, alkoholizm, niedobór witaminy $\mathrm{B}_{12}$ i żelaza, wiąże się z zaburzeniami przewodnictwa dopaminergicznego [6]. Niektórzy uważają, że czynnikiem wyzwalającym rozwój tej choroby może być traumatyczne wydarzenie. Pacjent, nie mogąc poradzić sobie z trudną sytuacją, uruchamia mechanizmy obronne $\mathrm{w}$ formie przeniesienia. W efekcie emocje związane z przykrym wydarzeniem zostają zastąpione przez objawy obłędu pasożytniczego [12].

Podstawowym objawem obłędu pasożytniczego jest fałszywe i niezachwiane przekonanie o obecności 
content reported by patients is characteristic. Usually, this belief is additionally supported by various sensory experiences, interpreted as the so-called tactile hallucinations - itching, tingling or burning of the skin, a sensation of crawling under the skin, and sometimes even pain. These symptoms are always accompanied by a subjective certainty that the reported ailments are caused by the presence of parasites [6]. Many patients are able to pinpoint the exact situation in which they were infected with parasites. Sometimes they spin conspiracy theories about their infection [15]. Patients usually accurately describe the appearance of alleged parasites, often draw them, and even try to catch and collect them. In order to convince the doctor of correctness of their beliefs, many patients deliver alleged parasites to their doctors in various boxes, bottles, jars, and plastic bags. In fact, these are most often pieces of damaged tissue, scabs of healing wounds, fragments of the epidermis, crumbs, dust particles, etc. This phenomenon is referred to in the literature as a "matchbox symptom" and is considered a pathognomonic symptom for delusional parasitosis [4,5]. Moreover, patients who want to prove the existence of a parasitic infection often subject the collected materials to numerous microbiological tests [5]. They repeatedly attempt antiparasitic treatment.

Delusional parasitosis may proceed without skin lesions, but in most cases skin manifestation is found. Skin lesions observed in the course of this disease are most often various types of mechanical damage to the skin of artificial origin and are the result of scratching or attempts of manual removal of alleged parasites. Most often, patients try to remove parasites with their own hands, but there are also attempts to use, for example, tweezers, scissors or pliers. Skin lesions of a self-mutilating nature (so-called dermatitis artefacta) are found on physical examination - incisions, scratches, erosions and ulcers, often accompanied by signs of secondary bacterial superinfection, as well as post-inflammatory scars, hyperpigmentation and discoloration. Skin lesions can affect virtually any part of the body. Characteristic, however, is the asymmetric location of efflorescence, which is described as the socalled "hand effect". Skin lesions are located within the patient's reach, and their intensity is higher on the side opposite to the patient's dominant hand.

Additionally, patients often attempt to disinfect and cleanse the skin of suspected parasites, using numerous, even highly corrosive, chemicals for this purpose, e.g., spirit, gasoline or various cleaning agents. Secondary to such actions, not only further skin damage is observed, but also the development of contact dermatitis, scarring, as well as post-inflammatory hyperpigmentation and discoloration. Initially, patients are able to lead a normal life. With time, delusions w skórze lub na jej powierzchni pasożytów (rzadziej bakterii, grzybów, wirusów). Niekiedy chorzy zgłaszają obecność pasożytów również w otoczeniu, np. na ubraniach, pościeli, meblach $[1,8]$. Przekonanie to podtrzymują pomimo braku jakichkolwiek medycznych dowodów na istnienie infekcji pasożytniczej [1, 6]. Charakterystyczny jest brak krytycyzmu wobec zgłaszanych treści wytwórczych. Zwykle przekonanie to jest dodatkowo poparte różnymi doznaniami czuciowymi, tzw. omamami dotykowymi, takimi jak świąd, mrowienie lub pieczenie skóry, uczucie pełzania pod skórą, a nawet dolegliwości bólowe. Objawom tym zawsze towarzyszy subiektywna pewność, że zgłaszane dolegliwości są spowodowane obecnością pasożytów [6]. Wielu pacjentów potrafi dokładnie wskazać sytuację, w której doszło do zainfekowania pasożytami. Zdarza się, że snują teorie spiskowe dotyczące swojego zakażenia [15]. Chorzy zazwyczaj dokładnie opisują wygląd domniemanych pasożytów, często je rysują, a nawet próbują łapać i zbierać. W celu przekonania lekarza o słuszności swoich przekonań wielu pacjentów przynosi na wizyty lekarskie domniemane pasożyty w różnych pudełkach, butelkach, słoikach, foliowych woreczkach. W rzeczywistości są to najczęściej kawałki uszkodzonych tkanek, strupy gojących się ran, fragmenty naskórka, okruszki, drobinki kurzu itd. Zjawisko to w piśmiennictwie określa się jako objaw pudełka od zapałek lub objaw próbki (matchbox sign). Jest ono uważane za patognomoniczny objaw obłędu pasożytniczego [4, 5]. Pacjenci, chcąc udowodnić istnienie infekcji pasożytniczej, często poddają zebrane materiały badaniom mikrobiologicznym [5]. Nieraz wielokrotnie podejmują próby leczenia przeciwpasożytniczego.

Obłęd pasożytniczy może przebiegać bez obecności zmian skórnych, jednak w większości przypadków stwierdza się manifestację skórną. Obserwowane w przebiegu tego schorzenia zmiany skórne mają najczęściej postać różnego rodzaju mechanicznych uszkodzeń pochodzenia artyficjalnego i stanowią wynik drapania lub prób manualnego usunięcia domniemanych pasożytów. Najczęściej pacjenci próbują usuwać pasożyty rękami, ale zdarza się też, że używają pęset, nożyczek, cążków itp. Klinicznie stwierdza się zmiany skórne w formie samouszkodzeń (tzw. dermatitis artefacta) - przeczosy, wydrapania, nadżerki i owrzodzenia, często z towarzyszącymi cechami wtórnego nadkażenia bakteryjnego, a także blizny, przebarwienia i odbarwienia pozapalne. Zmiany skórne mogą obejmować każdą część skóry. Charakterystyczna jest jednak asymetryczna lokalizacja wykwitów, opisywana jako tzw. efekt ręki. Zmiany skórne zlokalizowane są w zasięgu ręki chorego, a ich nasilenie stwierdza się po stronie przeciwnej do ręki dominującej.

Dodatkowo chorzy często podejmują próby dezynfekowania i oczyszczenia skóry z domniemanych 
attract more and more attention, and behavior related to attempts to get rid of parasites becomes obsessive $[9,15]$. Their only goal is to fight the alleged infection. As a result, patients neglect their duties, often resign from work and social contacts. This behavior leads to loneliness, and often also to financial problems, which further aggravates their stress and frustration. Patients often complain on being misunderstood or disregarded by other people, including doctors. This can lead to development of depressive disorders. It also happens that patients express suicidal thoughts [15]. The diagnosis of delusional parasitosis, like other delusional disorders, is an indication for initiation of antipsychotic treatment. So far, no general rules for the use of antipsychotics in this disease have been developed. There are also no randomized, controlled trials assessing the effectiveness of individual agents. Knowledge on this subject is based mainly on case reports available in the literature. In the past, first-generation antipsychotics, i.e., pimozide, were widely used to treat delusional parasitosis, but at present they are not recommended due to adverse effects [16]. Currently, second-generation (atypical) neuroleptics such as quetiapine, olanzapine, risperidone and aripiprazole are recommended, in their lowest possible doses, to prevent adverse effects, such as prolongation of the QT interval, extrapyramidal or metabolic disorders [17]. Reports available in the literature suggest the use of lower doses than in the case of schizophrenia. The suggested dose of olanzapine is $2.5-5 \mathrm{mg} /$ day, and of risperidone $1-2 \mathrm{mg} /$ day $[18,19]$. It seems that newer antipsychotics, such as lurasidone, paliperidone and brexpiprazole could offer some alternative. They have even fewer adverse effects, but their effectiveness in patients with delusional parasitosis need to be further confirmed in trials [20-23]. Selecting a specific drug, consideration should be given to the patient's other comorbidities and the adverse effect profile of that particular drug. In older patients, the dose should be adjusted to age, taking into account renal and hepatic function and other individual factors (e.g., heart failure). A final assessment of effects should be carried out after about 6 weeks of treatment. The time to maximum therapeutic effect varies and amounts to 10 weeks for the primary form and 3 weeks for the secondary form, respectively. Zomer et al. recommended continuation of antipsychotic treatment for another 6 weeks after symptoms had disappeared, and then discontinuation [24]. The therapy is chronic, often lasting for many years. Discontinuation of treatment after a clinical response is achieved often causes symptoms to recur [25]. In clinical practice, treatment of skin lesions resulting from delusional disorders must not be neglected. Often these are the only symptoms a patient reports to the doctor. Therapeutic manage- pasożytów, stosując do tego celu różne, często nawet żrące substancje chemiczne, takie jak spirytus, benzyna, środki czystości. Wtórnie do takich działań obserwuje się nie tylko dalsze uszkodzenie skóry, lecz także rozwój kontaktowego zapalenia skóry, bliznowacenia oraz przebarwień i odbarwień pozapalnych. Początkowo pacjenci są w stanie prowadzić normalne życie. Z czasem urojenia skupiają coraz więcej uwagi, a zachowania związane z próbami pozbycia się pasożytów stają się obsesyjne [9, 15]. Jedynym celem pacjenta staje się zwalczenie domniemanej infekcji. W efekcie chorzy zaniedbują swoje obowiązki, często rezygnują z pracy i kontaktów społecznych. Takie zachowania prowadzą do samotności, a nierzadko także do problemów finansowych, co dodatkowo pogłębia stres i frustrację. Często pacjenci skarżą się na brak zrozumienia ze strony otoczenia, w tym ze strony lekarzy. Może to prowadzić do rozwoju zaburzeń depresyjnych. Zdarza się, że chorzy wyrażają myśli samobójcze [15]. Rozpoznanie obłędu pasożytniczego, podobnie jak innych zaburzeń urojeniowych, stanowi wskazanie do włączenia leczenia przeciwpsychotycznego. Dotychczas nie powstały ogólne zasady stosowania leków przeciwpsychotycznych w tym schorzeniu. Brakuje też kontrolowanych badań klinicznych z randomizacją oceniających skuteczność poszczególnych preparatów. Wiedza na ten temat opiera się głównie na dostępnych w literaturze opisach przypadków. W przeszłości w celu leczenia urojeń pasożytniczych powszechnie stosowano leki przeciwpsychotyczne I generacji, np. pimozyd, jednak obecnie nie są one zalecane $z$ uwagi na działania niepożądane [16]. Obecnie preferowane jest stosowanie neuroleptyków II generacji (atypowych), takich jak kwetiapina, olanzapina, risperidon i arypiprazol, w możliwie najniższej dawce, aby zapobiec działaniom niepożądanym, tj. wydłużeniu odstępu QT, zaburzeniom pozapiramidowym i metabolicznym [17]. Dostępne w piśmiennictwie doniesienia sugerują stosowanie mniejszych dawek niż w przypadku schizofrenii. Sugerowana dawka olanzapiny wynosi 2,5-5 mg/dobę, a risperidonu 1-2 mg/dobę [18, 19]. Wydaje się, że inną metodą leczenia mogą być nowsze leki przeciwpsychotyczne, tj. lurazydon, paliperydon i brekspiprazol, mające jeszcze mniej działań niepożądanych, jednak potrzebne są dalsze badania potwierdzające ich skuteczność w leczeniu pacjentów z obłędem pasożytniczym [20-23]. W wyborze konkretnego leku należy wziąć pod uwagę choroby współistniejące oraz profil działań niepożądanych. U starszych pacjentów dawkę należy dostosować do wieku, uwzględnić czynność nerek i wątroby oraz inne czynniki indywidualne (np. niewydolność serca). Ostateczna ocena efektów powinna zostać przeprowadzona po około 6 tygodniach. Czas wystąpienia maksymalnego efektu leczenia jest różny i wynosi 
ment is based mainly on the treatment of artificial lesions. It should be remembered that skin lesions often occur with the use of various objects, so there is a risk of superinfection. In extreme cases that may lead to sepsis. Single lesions usually heal well under occlusive dressings, that may additionally constitute some form of a mechanical barrier, making it difficult for the patient to access lesions. Apart from general psychiatric treatment, psychotherapy and relaxation therapy are helpful [26].

\section{CONCLUSIONS}

The treatment of delusional parasitosis requires an interdisciplinary approach, involving cooperation of a dermatologist and psychiatrist, and often also a psychologist. Introduction of psychiatric treatment is very difficult because of the patient's fears related to stigmatization and a strong belief that parasites, not mental illness, are responsible for the experienced problems. In treating delusional parasitosis, the patient's trust in the attending doctor is essential. This is especially true for patients whose lack of understanding has led to social isolation and development of depressive symptoms. It should be remembered that a patient with parasitic delusions is devoid of criticism and has no insight into his own condition. Any attempts to explain to the patient that there is no infection and parasites do not exist are inadvisable and weaken the patient's confidence in the doctor. A neutral attitude towards the reality perceived by the patient is recommended - it should not be rejected or corrected, and at the same time it should not be confirmed. This approach allows the physician to create a good cooperation with the patient and obtain the patient's consent for the suggested therapy. Usually, it is easier for a patient to accept treatment prescribed by a dermatologist than by a psychiatrist.

\section{CONFLICT OF INTEREST}

The authors declare no conflict of interest.
10 tygodni dla postaci pierwotnej oraz 3 tygodnie dla postaci wtórnej. Zomer i wsp. zalecili kontynuowanie leczenia przeciwpsychotycznego przez kolejne 6 tygodni po ustąpieniu objawów, a następnie odstawienie leczenia [24]. Terapia jest przewlekła, często wieloletnia. Przerwanie leczenia po uzyskaniu odpowiedzi klinicznej często powoduje nawrót objawów [25]. W praktyce nie należy zapominać o leczeniu zmian skórnych będących skutkiem zaburzeń urojeniowych w postaci obłędu pasożytniczego. Nierzadko są to jedyne objawy, z którymi pacjent zgłasza się do lekarza. Postępowanie terapeutyczne polega głównie na leczeniu zmian artyficjalnych. Należy pamiętać, że zmiany skórne często powstają przy użyciu różnych przedmiotów, dlatego istnieje ryzyko nadkażeń, w skrajnych przypadkach mogących prowadzić do posocznicy. Pojedyncze zmiany zwykle dobrze się goją pod opatrunkami okluzyjnymi, które dodatkowo mogą stanowić formę bariery mechanicznej utrudniającej pacjentowi dostęp do zmian. Oprócz leczenia ogólnego psychiatrycznego pomocne są psychoterapia i terapia relaksacyjna [26].

\section{WNIOSKI}

Leczenie obłędu pasożytniczego wymaga podejścia interdyscyplinarnego, polegającego na współpracy dermatologa i psychiatry, a także często psychologa. Rozpoczęcie leczenia psychiatrycznego jest bardzo trudne ze względu na obawy pacjenta związane ze stygmatyzacją oraz silne przekonanie, że za zgłaszane przez niego dolegliwości odpowiedzialne są pasożyty, a nie choroba psychiczna. W terapii obłędu pasożytniczego niezbędne jest zaufanie pacjenta do lekarza. Jest to szczególnie istotne w przypadku pacjentów, u których brak zrozumienia doprowadził do izolacji społecznej i rozwoju objawów depresyjnych. Należy pamiętać, że chory, u którego występują urojenia pasożytnicze, jest pozbawiony krytycyzmu i nie ma wglądu we własną chorobę. Wszelkie próby wyjaśnienia pacjentowi, że nie ma zakażenia, a pasożyty nie istnieją, są niewskazane i prowadzą do osłabienia zaufania pacjenta do lekarza. Zalecana jest neutralna postawa wobec rzeczywistości postrzeganej przez chorego - nie powinno się jej odrzucać ani korygować, a jednocześnie nie powinno się jej potwierdzać. Takie podejście pozwala lekarzowi na stworzenie dobrej współpracy z pacjentem i uzyskanie jego zgody na zaproponowaną terapię. Zwykle choremu łatwiej jest zaakceptować leczenie przepisane przez dermatologa niż przez psychiatrę.

\section{KONFLIKT INTERESÓW}

Autorzy nie zgłaszają konfliktu interesów. 


\section{References}

\section{Piśmiennictwo}

1. Szepietowski J., Pacan P., Reich A., Grzesiak M.: Psychodermatologia. Akademia Medyczna we Wrocławiu, Wrocław, 2015.

2. Jafferany M., Franca K.: Psychodermatology: basics concepts. Acta Derm Venereol 2016, 96, 35-37.

3. Seyhan M., Aki T., Karincaoglu Y, Ozcan H.: Psychiatric morbidity in dermatology patients: frequency and results of consultations. Indian J Dermatol 2006, 51, 18-22.

4. Koo J.Y., Lee C.S.: General approach to evaluating psycho-dermatological disorders. [In:] Psychocutaneous Medicine. J.Y. Koo, C.S. Lee (eds.). Marcel Dekker Inc, New York, 2003, 1-29.

5. WHO. Klasyfikacja zaburzeń psychicznych i zaburzeń zachowania w ICD-10. Kraków-Warszawa, Vesalius, 2000.

6. Reich A., Kwiatkowska D., Pacan P.: Delusions of parasitosis: an update. Dermatol Ther 2019, 9, 631-638.

7. Friedmann A.C., Ekeowa-Anderson A., Taylor R., Bewley A.: Delusional parasitosis presenting as folie a' trois: successful treatment with risperidone. Br J Dermatol 2006, 155, 841-842.

8. Freudenmann R.W., Lepping P.: Delusional infestation. Clin Microbiol Rev 2009, 22, 690-732.

9. Szepietowski J.C., Salomon J., Hrehorow E., Pacan P., Zalewska A., Sysa-Jedrzejowska A.: Delusional parasitosis in dermatological practice. J Eur Acad Dermatol Venereol 2007, 21, 462-465.

10. Wykoff R.F.: Delusions of parasitosis: a review. Rev Infect Dis 1987, 9, 433-437.

11. Trabert W.: 100 years of delusional parasitosis. Psychopathology 1995, 28, 238-246.

12. Wong J.W., Koo J.Y.: Delusions of parasitosis. Indian J Dermatol 2013, 58, 49-52.

13. Huber M., Kirchler E., Karner M., Pycha R.: Delusional parasitosis and the dopamine transporter. A new insight of etiology? Med Hypotheses 2007, 68, 1351-1358.

14. Ochiai S., Sugawara H., Kajio Y., Tanaka H., Ischikawa T., Fukuhara R., et al.: Delusional parasitosis in dementia with Lewy bodies: a case report. Ann Gen Psychiatry 2019, 30, 18-29.

15. Falkowska U., Adamczyk K., Adamczyk D., Soroka E., Petit V., Olajossy M.: Uncommon psychopathological syndromes in psychiatry. Curr Probl Psychiatry 2018, 19, 299-322.

16. Trabert W.: 100 years of delusional parasitosis. Meta-analysis of 1,223 case reports. Psychopathology 1995, 28, 238-246.

17. Davis J.M., Chen N., Glick I.D.: A meta-analysis of the efficacy of second-generation antipsychotics. Arch Gen Psychiatry 2003, 60, 553-564.

18. Freudenmann R.W., Lepping P.: Second-generation antipsychotics in primary and secondary delusional parasitosis: outcome and efficacy. J Clin Psychopharmacol 2008, 28, 500-508.

19. Huber M., Lepping P., Pycha R., Karner M., Schwitzer J., Freudenmann R.W.: Delusional infestation: treatment outcome with antipsychotics in 17 consecutive patients (using standardized reporting criteria). Gen Hosp Psychiatry 2011, 33, 604-611.

20. Das S., Barnwal P., Winston A.B., Mondal S., Saha I.: Brexpiprazole: so far so good. Ther Adv Psychopharmacol 2016, 6, 39-54.

21. Scarff J.R., Casey D.A.: Newer oral atypical antipsychotic agents: a review. P T 2011, 36, 832-838.

22. Cascade E., Kalali A.H., Mehra S., Meyer J.M.: Real-world data on atypical antipsychotic medication side effects. Psychiatry 2010, 7, 9-12.

23. Loebel A., Citrome L.: Lurasidone: a novel antipsychotic agent for the treatment of schizophrenia and bipolar depression. BJPsych Bull 2015, 39, 237-241.

24. Freudenmann R.W., Lepping P.: Second-generation antipsychotics in primary and secondary delusional parasitosis. J Clin Psychopharmacol 2008, 28, 500-508.

25. Martins A.C., Mendes C.P., Nico M.M.: Delusional infestation: a case series from a university dermatology center in Sao Paulo, Brazil. Int J Dermatol 2016, 55, 864-868.

26. Lavery M.J., Stull C., McCaw I., Anolik R.B.: Dermatitis artefacta. Clin Dermatol 2018, 36, 719-722.

Received: 10.11 .2020

Accepted: 15.03 .2021

Otrzymano: $10.11 .2020 \mathrm{r}$.

Zaakceptowano: $15.03 .2021 \mathrm{r}$.

How to cite this article

Stroynowska-Kosik J., Zyzak S., Biało-Wójcicka E.: Delusional parasitosis (Ekbom syndrome) - a psychodermatologic disorder. Dermatol Rev/Przegl Dermatol 2021, 108, 160-168. DOI: https://doi.org/10.5114/dr.2021.107288. 